\title{
Oxidation of Methanol, Formaldehyde and Formate by a Candida Species
}

\author{
By Takaaki FurII and Kenzo TonomurA \\ Fermentation Research Institute, Inage, Chiba
}

Received April 24, 1972

\begin{abstract}
1. The oxidation of methanol to carbon dioxide by Candida $\mathrm{N}-16$ grown on methanol was investigated. The presence of enzymes which catalyze the following reaction was found in the cell-free extract of the yeast employed; $\mathrm{CH}_{3} \mathrm{OH} \rightarrow \mathrm{HCHO} \rightarrow \mathrm{HCOOH} \rightarrow \mathrm{CO}_{2} .2$. Methanol was oxidized to formaldehyde by an alcohol oxidase. The reaction was as follows; $\mathrm{CH}_{3} \mathrm{OH} \rightarrow \mathrm{O}_{2} \rightarrow \mathrm{HCHO}+\mathrm{H}_{2} \mathrm{O}_{3}$. The alcohol oxidase was crystallized after purification by ammonium sulfate-precipitation and column chromatography using DEAE-Sephadex A-50. A prosthetic group of the enzyme was proved to be FAD. The enzyme possessed a broad specificity for alcohols such as methanol, ethanol, $n$-propanol, $n$-butanol and $n$-amylalcohol. The enzyme was inducibly formed only by the addition of methanol. 3. The oxidation of formaldehyde to formate was catalyzed by a NAD-linked dehydrogenase dependent on GSH. 4. Formate was oxidized by a NAD-linked dehydrogenase. 5. Catalase was also found in the extract, and methanol was chemically oxidized by the reaction of catalase and hydrogen peroxide which was generated by the alcohol oxidase system. 6. The oxidation pathway from methanol to carbon dioxide was also found in other methanol-utilizing yeasts such as Candida N-17, Saccharomyces $\mathrm{H}-1$ and Torulopsis $\mathrm{M}-1$.
\end{abstract}

Many studies on the metabolic pathway of methane and methanol have been reported. The oxidation of methanol is generally known to proceed as follows ${ }^{1 \sim \tau}$, $\mathrm{CH}_{3} \mathrm{OH} \rightarrow \mathrm{HCHO} \rightarrow$ $\mathrm{HCOOH} \rightarrow \mathrm{CO}_{2}$. Besides, the assimilation pathway of methanol by bacteria has been extensively investigated by Quayle et al. ${ }^{8 \sim 10}$ and by Kaneda and Roxburgh. ${ }^{2}$ Recently, Tani et al. ${ }^{11,12}$ have reported the crystallization and properties of an alcohol oxidase from methanol-utilizing yeast, Kloeckera sp. However, the overall oxidation of methanol to carbon dioxide by yeast has not been reported. The present paper deals with an enzyme system which catalyzes the oxidation of methanol to carbon dioxide in Candida N-16. The oxidation of methanol by other methanol-utilizing yeasts, Candida $\mathrm{N}-17$, Saccharomyces $\mathbf{H}-1$ and Torulopsis $\mathbf{M}-1$, is also described.

\section{METHODS}

Organism. Candida N-16, Candida N-17,13i Saccharomyces $\mathrm{H}-1^{13}$ and Torulopsis $\mathrm{M}-1$ were used in this study.

Culture. The composition of a culture medium was as follows: $\left(\mathrm{NH}_{4}\right)_{2} \mathrm{HPO}_{4}, 3 \mathrm{~g} ; \mathrm{KH}_{2} \mathrm{PO}_{4}, 1 \mathrm{~g}$; $\mathrm{MgSO}_{4} \cdot 7 \mathrm{H}_{2} \mathrm{O}, 0.4 \mathrm{~g} ; \mathrm{FeSO}_{4} \cdot 7 \mathrm{H}_{2} \mathrm{O}, 0.01 \mathrm{~g} ; \mathrm{CaCl}_{2}$. $2 \mathrm{H}_{2} \mathrm{O}, 0.02 \mathrm{~g} ; \mathrm{MnSO}_{4} \cdot 4 \mathrm{H}_{2} \mathrm{O}, 0.02 \mathrm{~g} ; \mathrm{ZnSO}_{4} \cdot 7 \mathrm{H}_{2} \mathrm{O}$, $0.02 \mathrm{~g}$; yeast extract, $0.1 \mathrm{~g}$; thiamine- $\mathrm{HCl}, 200 \mu \mathrm{g}$; biotin, $4 \mathrm{~kg}$ and distilled water, 1 liter. The medium was sterilized at $121^{\circ} \mathrm{C}$ for $15 \mathrm{~min}$ and then $10 \mathrm{~g}$ of methanol was added into 1 liter of the medium after cooling. The yeast was grown in a 1-liter Erlenmeyer flask containing $350 \mathrm{ml}$ of the medium on a rotary shaker $(180 \mathrm{rpm})$ for $48 \sim 72 \mathrm{hr}$ at $30^{\circ} \mathrm{C}$.

Preparation of cell-free extract. The yeast cells were harvested by centrifugation and washed with $50 \mathrm{~mm}$ phosphate buffer at $\mathrm{pH} 7.3$. The washed cells were suspended in the same buffer, and distrupted by shaking with glass beads $(0.25 \sim 0.30 \mathrm{~mm}$ in diameter) using a Braun's homogenizer. The homogenate was 
then centrifuged at $12,000 \mathrm{~g}$ for $30 \mathrm{~min}$ and the supernatant was dialyzed against $50 \mathrm{~mm}$ phosphate buffer at $\mathrm{pH} 7.3$.

Manometric assay. Oxygen consumption and carbon dioxide evolution were measured at $30^{\circ} \mathrm{C}$ in a Warburg apparatus.

Estimation of methanol. Methanol was assayed by gas chromatograph (TCD) using a column of $20 \%$ acetyl derivative of diethyleneglycol diadiplate on $60 \sim 80$ mesh of daifion (Daikinkogyo Co., Ltd.); column size, $3 \mathrm{~m} \times \phi 4 \mathrm{~mm}$; a temperature, $120^{\circ} \mathrm{C}$; a flow rate of carrier gas (hydrogen); $35 \mathrm{ml} / \mathrm{min}$.

Estimation of formaldehyde. Formaldehyde was assayed by a chromotropic acid method.14

Identification of formaldehyde. Formaldehyde was identified by melting-point and IR spectrum of its 2,4-dinitrophenylhydrazone. 2,4-Dinitrophenylhydrazone of formaldehyde was prepared as follows; the cell-free extract ( $4 \mathrm{mg}$ of protein) was incubated with 0.2 mmoles of phosphate buffer at pH 7.3 containing 2 mmoles of methanol for $30 \mathrm{~min}$ at $30^{\circ} \mathrm{C}$. Then, a 2,4-dinitrophenylhydrazine-acidified alcohol solution was added to the reaction mixture. The yellowish crystralline precipitates were separated by centrifugation and recrystallized from methanol. The melting-point of the compound was $164 \sim 165^{\circ} \mathrm{C}$.

Identification of formic acid. Formate was identified by thin-layer chromatography; the solvent, propanol $-28 \%$ ammonium water $(7: 3)$, was used and $0.04 \%(\mathrm{w} / \mathrm{v})$ bromocresol green in ethanol was sprayed. Furthermore, formic acid was confirmed as formylhydroxamic acid which was identified by thin-layer chromatography; the solvent, butanol-acetic acid-water (4: $1: 5$ ), was used and $5 \%(\mathrm{w} / \mathrm{v}) \mathrm{FeCl}_{3} \cdot 6 \mathrm{H}_{2} \mathrm{O}$ in ethanol was sprayed. Formylhydroxamic acid was prepared as follows; the cell-free extract ( $5 \mathrm{mg}$ of protein) was incubated with $200 \mu$ moles of phosphate buffer at pH 7.3 containing $200 \mu$ moles of formaldehyde, 50 $\mu$ moles of NAD and $50 \mu$ moles of GSH for $10 \mathrm{~min}$ at $30^{\circ} \mathrm{C}$. The reaction mixture was acidified with dil. sulfuric acid and then extracted with ether. The ether layer was neutralized with a dil. sodium hydroxide solution, and dried up under reduced pressure. To aliquote of the residue was added $2 \mathrm{ml}$ of an acidified methanol solution and kept for $24 \mathrm{hr}$ in a sealed tube for esterification. Formylhydroxamate was prepared by adding $3 \mathrm{ml}$ of a freshly mixed alkaline hydroxylamine solution to the methyl ester. The alkaline hydroxylamine solution was prepared as follows; nine volumes of a sodium methoxide solution was mixed with twenty volumes of a hydroxylamine solution, and the mixture was cooled to about $0^{\circ} \mathrm{C}$ and then resultant precipitate was removed.

Estimation of hydrogen peroxide. Hydrogen peroxide was enzymatically estimated essentially according to Jermyn and Thomas. ${ }^{15)}$ The assay mixture contained $0.2 \mathrm{ml}$ of a peroxidase solution (18 units, Boehringer), $0.1 \mathrm{ml}$ of $0.22 \%(\mathrm{v} / \mathrm{v})$ guiacol, $2.65 \mathrm{ml}$ of $50 \mathrm{~mm}$ phosphate buffer at $\mathrm{pH} 7.0$ and $0.05 \mathrm{ml}$ of a hydrogen peroxide solution. Optical density was measured at $435 \mathrm{~m} \mu$.

Purification and crystallization of alcohol oxidase. The crude extract was prepared from $27 \mathrm{~g}$ (dry wt.) of frozen methanol-grown yeast. The yeast was disrupted by a Braun's homogenizer. To the extract, $7.5 \mathrm{~g}$ of streptomycine was added and the resultant precipitate was removed by centrifugation. Solid ammonium sulfate was added to the supernatant so that $80 \%$ saturation was given. After $30 \mathrm{~min}$ the precipitate was centrifuged, resuspened in a small amount of $50 \mathrm{~mm}$ phosphate buffer at $\mathrm{pH} 7.3$ and then dialyzed against the same buffer overnight. The dialyzate was again fractionated with ammonium sulfate at the concentration between $40 \sim 70 \%$ satulation and then dialyzed. The dialyzate (752 $\mathrm{mg}$ of protein) was subjected to chromatography on a DEAE-Sephadex A-50 column $(45 \times 2.5 \mathrm{~cm})$. It was eluted by gradient concentrations of sodium chloride $(0 \sim 500 \mathrm{~mm})$ dissolve in $50 \mathrm{~mm}$ phosphate buffer $(\mathrm{pH} \mathrm{7.3)}$ at a flow rate of $5 \mathrm{ml} / \mathrm{hr}$. Each fraction was collected in $10 \mathrm{ml}$. Alcohol oxidase was found in fractions from No. 78 to No. 87 (Fig. 1). These fractions were combined

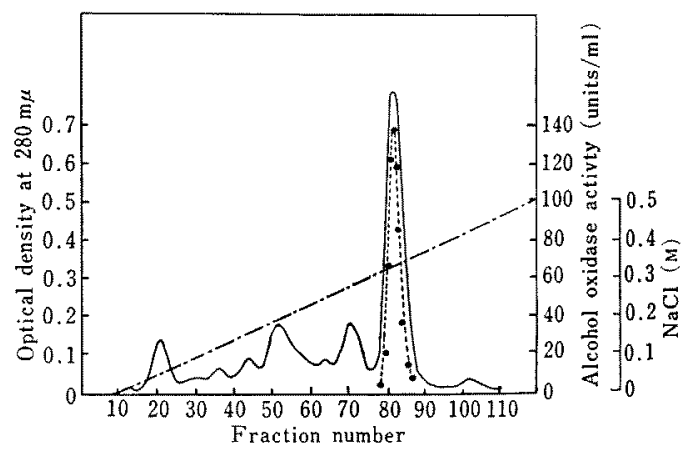

FIG. 1. Chromatography of Alcohol Oxidase on a DEAE-Sephadex A-50 Column.

The method is described in the text.

$\longrightarrow$, optical density at $280 \mathrm{~m} \mu$; --.e, Activity of alcohol oxidase; - - - $\mathrm{NaCl}$ conc. 
Table I. Purification of Alcohol Oxidase

\begin{tabular}{lccccc}
\multicolumn{1}{c}{ Fraction } & $\begin{array}{c}\text { Volume } \\
(\mathrm{ml})\end{array}$ & $\begin{array}{c}\text { Total } \\
\text { activity } \\
\text { (units) }\end{array}$ & $\begin{array}{c}\text { Total } \\
\text { protein } \\
(\mathrm{mg})\end{array}$ & $\begin{array}{c}\text { Sp. activity } \\
\text { (units/mg } \\
\text { of protein) }\end{array}$ & $\begin{array}{c}\text { Yield } \\
(\%)\end{array}$ \\
\hline $\begin{array}{l}\text { crude extract } \\
\text { ammonium sulfate fractionation } \\
(80 \% \text { sat.) }\end{array}$ & 300 & 18,370 & 5,775 & 3.27 & 100 \\
$\begin{array}{l}\text { ammonium sulfate fractionation } \\
(40 \sim 70 \% \text { sat.) }\end{array}$ & 200 & 16,800 & 1,180 & 14.23 & 71.4 \\
$\begin{array}{l}\text { DEAE-Sephadex chromatography } \\
\text { DEAE-Sephadex re-chromatography }\end{array}$ & 22 & 12,540 & 752 & 19.44 & 68.1 \\
\hline
\end{tabular}

a) The fractions having oxidase activity were combined and concentrated by a collodion bag.

and concentrated by a collodion bag, and then subjected to rechromatography on a DEAE-Sephadex A-50 column. The purification is summarized in Table I. Fractions having the oxidase activity were combined and concentrated by a collodion bag. The concentrated solution was kept to stand at $4^{\circ} \mathrm{C}$ in reduced pressure after solid ammonium sulfate was slowly added with stirring so that the concentration reached $30 \%$ saturation. After one week crystals began to form.

Polyacrylamide gel electrophoresis of alcohol oxidase. Electrophoresis was carried out on a $7.5 \%$ polyacrylamide gel column at $\mathrm{pH} 9.4$ for approximately $90 \mathrm{~min}$ at $3 \mathrm{~mA}$. The oxidase was detected by staining with amidoshwarz.

Assay of enzyme activities

a) Alcohol oxidase. The activity was manometrically assayed by measuring the rate of oxygen consumption. In the main compartment of a Warburg flask were placed $0.1 \sim 1.0 \mathrm{ml}$ of an enzyme solution and $200 \mu$ moles of phosphate buffer at $\mathrm{pH} 7.3$. In the center well was placed $0.2 \mathrm{ml}$ of $20 \%(\mathrm{w} / \mathrm{v})$ potassium hydroxide. In the side arm were placed $100 /$ moles of methanol. The total volume was $3.2 \mathrm{ml}$. Incubation was carried out at $30^{\circ} \mathrm{C}$. One unit of an activity was defined as the amount of an enzyme which catalyzes the consumption of $10 \mu$ of oxygen for 10 min under these conditions.

b) Formaldehyde dehydrogenase. The enzyme was spectrophotometrically assayed by the method of Rase and Racker. ${ }^{16\}}$ The reaction mixture was consisted of an enzyme solution, $100 \mu$ moles of formaldehyde, $2 \mu$ moles of NAD, $10 \mu$ moles of GSH and $100 \mu$ moles of phosphate buffer at pH 7.3. The final volume was $3.0 \mathrm{ml}$. Cyanide which is known as an inhibitor of a reduced-NAD oxidation system was not added to the reaction mixture, since cyanide reacts with formaldehyde.

c) Formate dehydrogenase. The enzyme was manometrically assayed essentially according to Davison. ${ }^{17}$, In the main compartment of a Warburg flask were placed an enzyme solution, 2 mmoles of $\mathrm{NAD}, 0.5 \mathrm{ml}$ of $0.01 \%(\mathrm{w} / \mathrm{v})$ methylene blue and $100 \mu$ moles of phosphate buffer at $\mathrm{pH} 7.3$. In the center well was placed $0.2 \mathrm{ml}$ of $20 \%(\mathrm{w} / \mathrm{v})$ potassium hydroxide. In the side arm were placed $100 \mu$ moles of sodium formate. The final volume was $3.2 \mathrm{ml}$. Incubation was carried out at $30^{\circ} \mathrm{C}$.

d) Alcohol dehydrogenase. The enzyme was spectrophotometrically assayed by the method of Wenger and Bernofsky. ${ }^{181}$ The reaction mixture was consisted of an enzyme solution, $100 \mu$ moles of ethanol, $2 \mu$ moles of NAD, $1 \mu$ mole of potassium cyanide and $100 \mu$ moles of phosphate buffer at $\mathrm{pH} 7.3$. The final volume was $3.0 \mathrm{ml}$.

e) Catalase. The activity was assayed by a manometric method. In the main compartment of a Warburg flask were placed an enzyme solution and $100 \mu$ moles of phosphate buffer at $\mathrm{pH} \mathrm{7.3.} \mathrm{In} \mathrm{the}$ center well was placed $0.2 \mathrm{ml}$ of $20 \%(\mathrm{w} / \mathrm{v})$ potassium hydroxide. In the side arm were placed $100 \mu$ moles of hydrogen peroxide. The final volume was $3.2 \mathrm{ml}$. Incubation was carried out at $30^{\circ} \mathrm{C}$.

Protein determination. Protein was determined by the Folin-Ciocalteu method. ${ }^{19}$

\section{RESULTS}

Oxidation of methanol, formaldehyde and formate by Candida $N-16$ 
The total oxygen consumption by the washed cells of methanol-grown Candida N-16 was manometrically measured in the presence of methanol, formaldehyde and formate, respectively. The result shown in Fig. 2 suggests

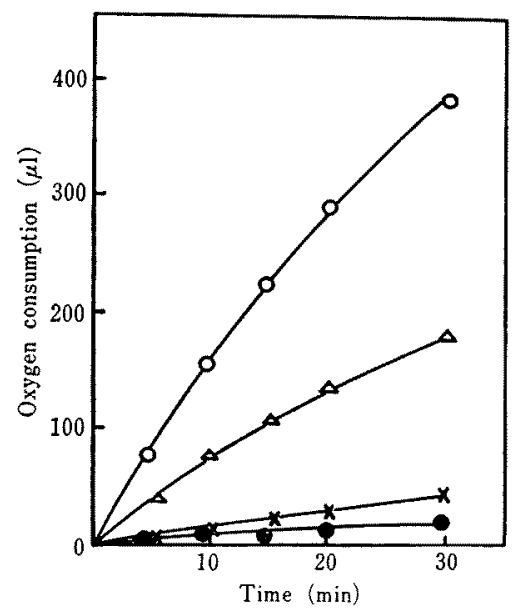

FIG. 2. Oxidation of Methanol, Formaldehyde and Formate by Washed Cells of Methanol-Grown Candida $\mathrm{N}-16$.

In the main compartment of a Warburg flask were placed $1.0 \mathrm{ml}$ of cell suspension $(2.4 \mathrm{mg}$ dry wt. of cells) and $200 \mu$ moles of phosphate buffer at $\mathrm{pH} 7.3$. In the side arm were placed $100 \mu$ moles of substrate. In the center well was placed $0.2 \mathrm{ml}$ of $20 \%(\mathrm{w} / \mathrm{v}) \mathrm{KOH}$. The total volume was $3.2 \mathrm{ml}$. Incubation was carried out at $30^{\circ} \mathrm{C}$.

$\bigcirc-O$, methanol; $\triangle-\Delta$, formaldehyde; $x-x$, formate; - no substrate.

that enzymes catalyzing the oxidation of these compounds are present in the methanol-grown yeast. The initial rate of oxygen consumption in the presence of methanol was about fifteen times greater than that of formate. To investigate the great difference of the oxygen consumption rate between methanol and formate, the reduction rate of methylene blue by cell suspension was measured in the presence of these compounds. As shown in Table II, the dye was not reduced in the presence of methanol, but the reduction of dye was observed by the addition of formate. A
Table II. Reduction of Methylene Blue by Washed Cells of Candida N-16 IN the Presence of Methanol or Formate

The reaction mixture was consisted of cell suspension $(1.2 \mathrm{mg}$ dry wt. of cells), $200 \mu$ moles of a substrate, $200 \mu$ moles of phosphate buffer at $\mathrm{pH} 7.3$ and $0.5 \mathrm{ml}$ of $0.01 \%(\mathrm{w} / \mathrm{v})$ methylene blue. The total volume was $5.0 \mathrm{ml}$. A control without substrate was also incubated. The incubation time necessary for decolorization of methylene blue was measured at $30^{\circ} \mathrm{C}$ under anaerobic conditions using a Thunberg tube.

\begin{tabular}{lc}
\hline \multicolumn{1}{c}{ Substrate } & Reduction of methylene blue \\
\hline $\begin{array}{l}\text { Methanol } \\
\text { Formate }\end{array}$ & - \\
\hline
\end{tabular}

similar result was obtained in the reduction of 2,6-dichlorophenol indophenol. It was known that the organic dyes, such as methylene blue, are capable of being the hydrogen acceptor in an oxidation-reduction system catalyzed by some dehydrogenases. Therefore, it is suggested that the oxidation mechanism of methanol may be different from that of formate.

Oxidation of methanol by the cell-free extract of Candida $\mathrm{N}-16$

As shown in Fig. 3, oxygen was consumed by the cell-free extract when methanol was used as a substrate, whereas the consumption of oxygen was not observed when formaldehyde or formate was added to the extract. The consumption of oxygen in the presence of methanol was not inhibited by the addition of cyanide which is known as an inhibitor of cytochrome-oxidation.

Formaldehyde was produced during the oxidation of methanol by the extract. It was confirmed as 2,4-dinitrophenylhydrazone of formaldehyde by melting-point and IR spectrum, as described in Methods. When the extract was incubated with methanol in the presence of nitrogen instead of air using a Thunberg tube, the formation of formaldehyde was not observed, as shown in Fig. 4. It 


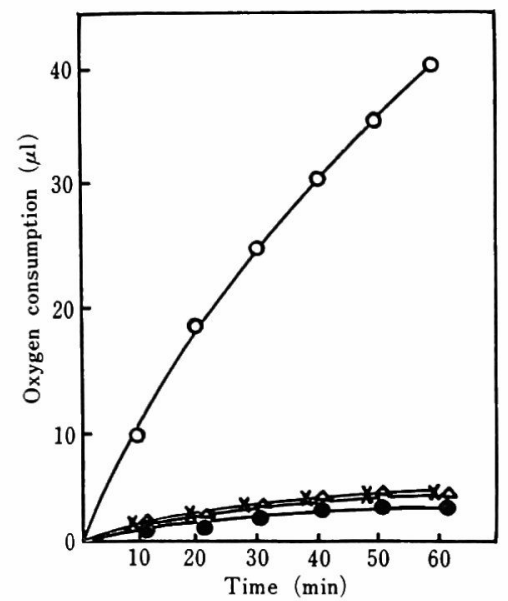

Fig. 3. Consumption of Oxygen by Cell-free Extract of Candida N-16 in the Presence of Methanol, Formaldehyde and Formate, Respectively.

The method is shown in Fig. 2 except that in a main compartment was placed $0.1 \mathrm{ml}$ of the extract (190 $\mu \mathrm{g}$ of protein) instead of the cell suspension.

$\mathrm{-} \mathrm{O}$, methanol; $\triangle-\triangle$, formaldehyde; $\times-\times$, formate; - no substrate.

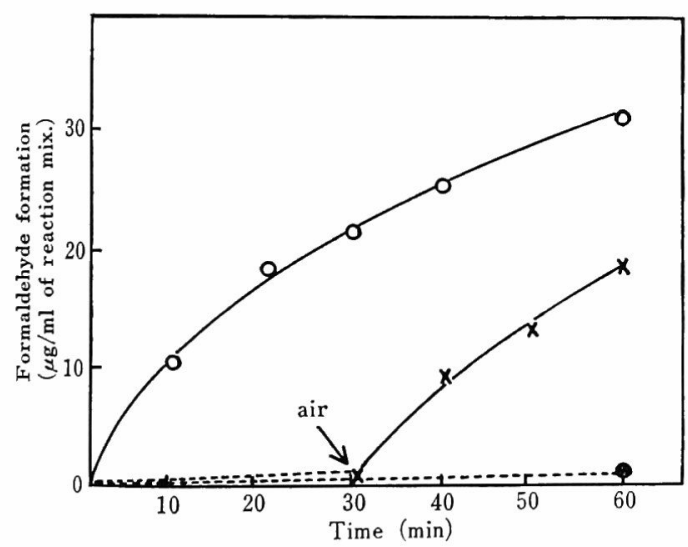

FIG. 4. Effect of Oxygen on Oxidation of Methanol to Formaldehyde by Cell-free Extract of Candida $\mathrm{N}-16$.

The reaction mixture was consisted of $1.0 \mathrm{ml}$ of the extract (1.9 mg of protein), $100 \mu$ moles of methanol and $200 \mu$ moles of phosphate buffer at $\mathrm{pH}$ 7.3. The total volume was $5.0 \mathrm{ml}$. Incubation was carried out at $30^{\circ} \mathrm{C}$ under aerobic (air) or anaerobic (replaced by nitrogen) conditions using a Thunberg tube.

0 , aerobic; $\times$, re-replaced by air after $30 \mathrm{~min}$; ๑, anaerobic. could not be observed even when NAD, NADP, FAD, phenazine methosulphate or methylene blue was supplemented to the incubation medium. When the nitrogen was replaced by air after 30 -min incubation, the formation of formaldehyde was observed.

\section{Preparation and properties of alcohol oxidase}

The enzyme which catalyzes the oxidation of methanol to formaldehyde was purified by ammonium sulfate-fractionation and chromatography using a DEAE-Sephadex A-50 column. The purified enzyme was found to be homogeneous on polyacrylamide gel electrophoresis. By adding solid ammonium sulfate to the purified enzyme solution a yellowish crystalline enzyme was obtained. (Fig. 5)

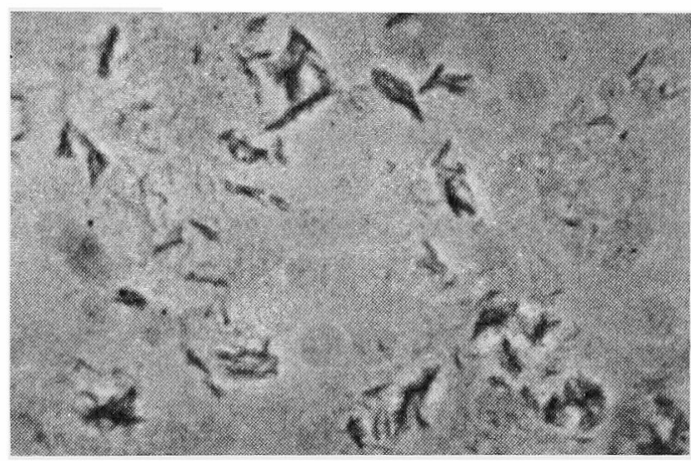

FIG. 5. Micrograph of Crystalline Alcohol Oxidase.

The $K m$ value for methanol and ethanol at pH 7.3 at $30^{\circ} \mathrm{C}$ was $2.12 \times 10^{-3} \mathrm{M}$ and $2.62 \times$ $10^{-3} \mathrm{M}$, respectively. The optimum $\mathrm{pH}$ was 7.0 9.5. The optimum temperature was $35^{\circ} \mathrm{C}$. The activity was completely lost when the enzyme was either kept at pH 5.7 for $12 \mathrm{hr}$, freezed and thawed, or heated at $55^{\circ} \mathrm{C}$ for $10 \mathrm{~min}$, but the enzyme was stable to strorage at $4{ }^{\circ} \mathrm{C}$ in $50 \mathrm{~mm}$ phosphate buffer at $\mathrm{pH} 7.3$ for a long time. The molecular weight of the enzyme was estimated to be 210,000 by the method of gel-filtration on Sephadex G-200. The enzyme showed a maximum absorption at $383 \mathrm{~m} \mu$ and $458 \mathrm{~m} \mu$ in visible range. This 
suggested that a flavin compound was present in it. It was found that a prosthetic group of the enzyme was FAD by thin-layer chromatography on a cellulose plate according to the method of Pazur and Kleppe. ${ }^{201}$ The substrate specificity is shown in Table III. The result was very similar to that of alcohol oxidase of Kloeckera sp. indicated by Tani et al. ${ }^{11,121}$

Table III. Substrate Specificity of AlCOHOL OXIDASE

The assay mixture was consisted of $30 \mu \mathrm{g}$ of the purified enzyme and $100 \mu$ moles of a substrate. The enzyme activity was manometrically measured as described in the text.

\begin{tabular}{lc}
\multicolumn{1}{c}{ Substrate } & Relative enzyme activity \\
\hline Methanol & 100 \\
Ethanol & 92.7 \\
$n$-Propanol & 75.4 \\
$n$-Butanol & 58.4 \\
n-Amyl alcohol & 39.6 \\
Benzyl alcohol & 9.4 \\
Isopropanol & 7.5 \\
Isoamyl alcohol & 3.0 \\
sec-Butanol & 0 \\
tert-Butanol & 0 \\
Ethylene glycol & 10.0 \\
Propylene glycol & 1.1 \\
Glycerine & 0 \\
Methyl cellosolve & 12.2 \\
Glycolic acid & 0 \\
\hline
\end{tabular}

Hydrogen peroxide which was produced during the oxidation of methanol by the enzyme was determined by the method of guiacol oxidation in the presence of peroxidase.

The stoichiometry of the methanol oxidation is shown in Table IV, suggesting that the enzyme is an alcohol oxidase which catalyzes the following reaction:

$$
\mathrm{CH}_{3} \mathrm{OH}+\mathrm{O}_{2} \longrightarrow \mathrm{HCHO}+\mathrm{H}_{2} \mathrm{O}_{2}
$$

Role of catalase in the oxidation of methanol Harrington and $\mathrm{Kallio}^{3 ;}$ suggested that
Table IV. Stoichiometry of Methanol Oxidation BX Alcohol Oxidase

In the main compartment of a Warburg flask were placed $0.5 \mathrm{ml}$ of the purified enzyme ( $20 \mu \mathrm{g}$ of protein) and $250 \mu$ moles of phosphate buffer at $\mathrm{pH} 7.3$. In one side arm were placed $100 \mu$ moles of methanol and in the other was placed $0.5 \mathrm{ml}$ of $5 \%(\mathrm{v} / \mathrm{v})$ acetic acid. In the center well was placed $0.2 \mathrm{ml}$ of $20 \%$ $(w / v) \mathrm{KOH}$. The total volume was $3.2 \mathrm{ml}$. Incubation was carried out at $30^{\circ} \mathrm{C}$ for $30 \mathrm{~min}$. The reaction was stopped by adding acetic acid. Residual methanol, hydrogen peroxide, oxygen and formaldehyde were respectively assayed as described in the text.

\begin{tabular}{|c|c|c|c|}
\hline $\begin{array}{l}\text { Methanol } \\
\text { used } \\
\text { (//moles) }\end{array}$ & $\begin{array}{c}\text { Oxygen } \\
\text { consumed } \\
\text { (/mmoles) }\end{array}$ & $\begin{array}{l}\text { Hydrogen } \\
\text { peroxide } \\
\text { produced } \\
\text { ( } \mu \text { moles) }\end{array}$ & $\begin{array}{l}\text { Formaldehyde } \\
\text { produced } \\
\text { (umoles) }\end{array}$ \\
\hline 6.40 & 6.07 & 6.12 & 6.53 \\
\hline
\end{tabular}

methanol was oxidized by alcohol peroxidase in Pseudomonas methanica. The presence of catalase in the extract of Candida $\mathrm{N}-16$ was manometrically demonstrated. The formation of formaldehyde from methanol was stimulated by the addition of hydrogen peroxide to the extract, as shown in Fig. 6. Heim et al. ${ }^{21}$ indicated that catalase was reversibly inhibited by 3-amino-1,2,4-triazol. The catalase activity of the extract was inhibited virtually $90 \%$ in the presence of $10^{-1} \mathrm{M} 3$ amino-1,2,4-triazol. When the extract was preincubated with 3-amino-1,2,4-triazol and then hydrogen peroxide was added, the oxidation of methanol by hydrogen peroxide was not observed. As shown in Table IV, in the oxidation of methanol by the purified enzyme 1 mole of oxygen was consumed as 1 mole of formaldehyde and 1 mole of hydrogen peroxide were produced. In the case of the extract, 1 mole of oxygen was consumed as 2 moles of formaldehyde was produced, as shown in tract, 1 mole of oxygen was consumed as 2 moles of formaldehyde was produced, as shown in Table V. These facts suggest that the methanol oxidation by the extract is cata- 


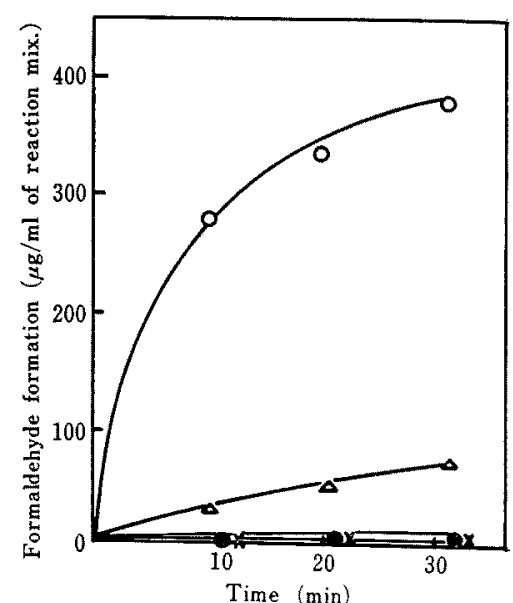

Fig. 6. Effect of Hydrogen Peroxide on MethanoiOxidation by Cell-free Extract of Candida $\mathrm{N}-16$.

The reaction mixture was consisted of $0.5 \mathrm{ml}$ of the extract ( $650 \mu \mathrm{g}$ of protein), 1 mmole of methanol, 0.3 mmoles of $\mathrm{H}_{2} \mathrm{O}_{2}$ and 0.2 mmoles of phosphate buffer at $\mathrm{pH} 7.3$. The total volume was $5.0 \mathrm{ml}$. Incubation was carried out at $30^{\circ} \mathrm{C}$.

$\mathrm{O}-\mathrm{O}$, extract $+\mathrm{H}_{2} \mathrm{O}_{2}+$ methanol; $\Delta-\Delta$, extract tmethanol; $x-\times$, methanol $+\mathrm{H}_{2} \mathrm{O}_{2} ; \bullet-\bullet$, no substrate.

Table V. Stoichiometry of Methanol Oxidation by Cell Free Extract of Candida N-16

The method is shown in Table IV except that in the main compartment of a Warburg flask was placed $0.1 \mathrm{ml}$ of the extract (190 $\mu \mathrm{g}$ of protein) instead of the purified enzyme. Incubation was carried out at $30^{\circ} \mathrm{C}$ for $90 \mathrm{~min}$.

\begin{tabular}{cc}
\hline $\begin{array}{c}\text { Oxygen } \\
\text { consumed } \\
(\mu \text { moles })\end{array}$ & $\begin{array}{c}\text { Formaldehyde } \\
\text { produced } \\
(\mu \text { moles })\end{array}$ \\
\hline 2.2 & 4.3 \\
\hline
\end{tabular}

lyzed by alcohol oxidase and also by catalase and hydrogen peroxide which is generated by the alcohol oxidase reaction.

Oxidation of formaldehyde to formate by the cell-free extract of Candida $N-16$

Figure 7 shows that formaldehyde was disappeared when NAD or NAD plus GSH was added to the extract. NAD was reduced when formaldehyde was incubated with the

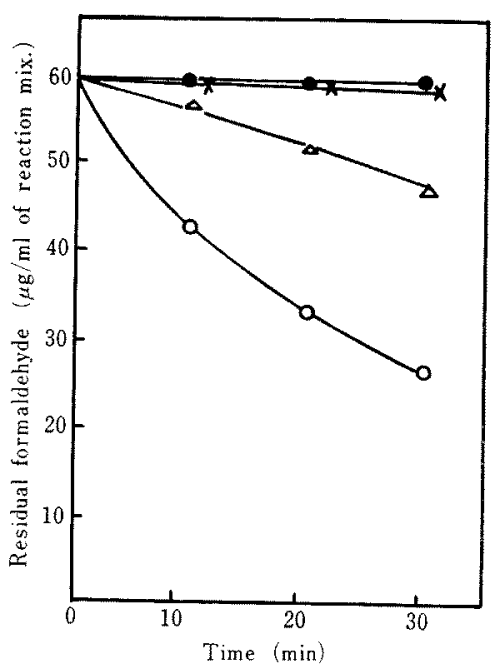

FIG. 7. Disappearance of Formaldehyde during the Incubation of Cell-free Extract of Candida N-16.

The reaction mixture was consisted of $0.5 \mathrm{ml}$ of the extract $(950 \mu \mathrm{g}$ of protein), $10 \mu$ moles of formaldehyde and $200 \mu$ moles of phosphate buffer at $\mathrm{pH} 7.3$. Ten $\mu$ moles of NAD and $10 \mu$ moles of GSH were added. The total volume was $5.0 \mathrm{ml}$. Incubation was carried out at $30^{\circ} \mathrm{C}$.

$0-\mathrm{O}, \mathrm{NAD}+\mathrm{GSH} ; \triangle-\triangle$, NAD; $\times-\times, \mathrm{GSH}$;

- - NAD and GSH omitted.

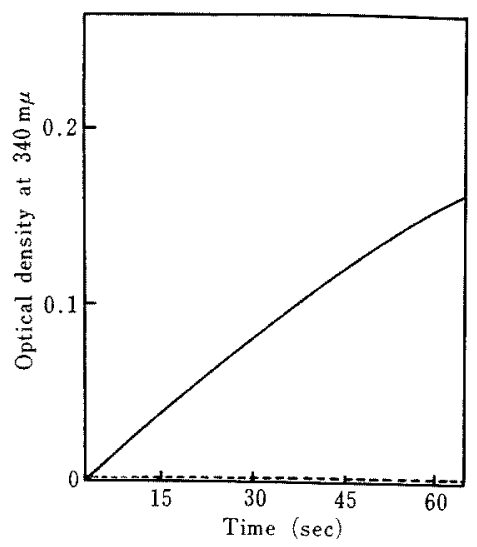

FIG. 8. Reduction of NAD in the Presence of Formate by Cell-free Extract of Candida N-16.

The reaction mixture was consisted of the extract $(3.5 \mathrm{mg}$ of protein), $100 \mu$ moles of sodium formate, $2 \mu$ moles of NAD and $200 \mu$ moles of phosphate buffer at $\mathrm{pH}$ 7.3. The total volume was $3.0 \mathrm{ml}$.

- a complete system; ---.--, formate omitted. 
Table Vi. Effect of Carbon Source on Formation of Enzymes Responsible for Oxidation of Methanol, Formaldehyde and Formate

Candida $\mathrm{N}-16$ was grown on the culture medium containing $1 \%(\mathrm{w} / \mathrm{v})$ carbon source at $30^{\circ} \mathrm{C}$ for $48 \sim 72 \mathrm{hr}$. The preparation of cell-free extract and an enzyme assay are shown in the text.

\begin{tabular}{lcccc}
\hline Substrate & $\begin{array}{c}\text { Alcohol } \\
\text { oxidase } \\
\text { (units } / \mu \mathrm{g} \\
\text { of protein) }\end{array}$ & $\begin{array}{c}\text { Formaldehyde } \\
\text { dehydrogenase } \\
\text { (units } / \mu \mathrm{g} \\
\text { of protein) }\end{array}$ & $\begin{array}{c}\text { Formate } \\
\text { dehydrogenase } \\
\text { (units } / \mu \mathrm{g} \\
\text { of protein) }\end{array}$ & $\begin{array}{c}\text { Alcohol } \\
\text { dehydrogenase } \\
\text { (units } / \mu \mathrm{g} \\
\text { of protein) }\end{array}$ \\
\hline $\begin{array}{l}\text { Methanol } \\
\text { Glucose }\end{array}$ & 2.5 & 0.18 & 0.34 & 0.56 \\
Ethanol & 0 & \pm & 0 & 0.59 \\
\hline
\end{tabular}

a An optical density at $340 \mathrm{~m} \mu$ increased slightly at the early stage of the reaction, and then it gradually decreased.

extract. The product of this reaction was demonstrated to be formate by thin layer chromatography as described in Methods. These results suggest that the oxidation of formaldehyde to formate may be catalyzed by an aldehyde dehydrogenase linked NAD, as follows:

$$
\mathrm{HCHO}+\mathrm{NAD}+\mathrm{H}_{2} \mathrm{O} \longrightarrow \mathrm{HCOOH}+\mathrm{NADH}_{2}
$$

Oxidation of formate by the extract of Candida $N-16$

As shown in Fig. 8, NAD was reduced when formate was incubated with the extract. Reduced NAD was oxidized by the addition of methylene blue. The consumption of oxygen and the evolution of carbon dioxide were manometrically assayed in the following oxidation-reduction system: $1.0 \mathrm{ml}$ of extract $(3.5$ $\mathrm{mg}$ of protein), $100 \mu$ moles of sodium formate, $2 \mu$ moles of NAD, $0.5 \mathrm{ml}$ of $0.01 \%(\mathrm{w} / \mathrm{v}) \mathrm{me}-$ thylene blue and $200 \mu$ moles of phosphate buffer at $\mathrm{pH} 7.3$. The total volume was $3.2 \mathrm{ml}$. Incubation was carried out at $30^{\circ} \mathrm{C}$ for $30 \mathrm{~min}$. It was found that $4.3 \mu$ moles of carbon dioxide was produced as $1.9 \mu$ moles of oxygen was consumed. The oxygen consumption may be accounted for the oxidation of reduced NAD in which an electron was transferred to oxygen through the intermediary of methylene blue. Therefore, it is suggested that a formate dehy. drogenase which catalyzes the following reaction was present in the extract of Candida
$\mathrm{N}-16$ :

$$
\mathrm{HCOOH}+\mathrm{NAD} \longrightarrow \mathrm{CO}_{2}+\mathrm{NADH}_{2}
$$

Inducible formation of an enzyme system responsible for the oxidation of methanol

Table VI shows that alcohol oxidase, formaldehyde dehydrogenase and formate dehydrogenase were all inducibly formed by the addition of methanol. Ethanol as well as methanol was oxidized by alcohol oxidase, as shown in Table III. But alcohol oxidase could not be found in the extract of ethanolgrown yeast. On the other hand, alcohol dehydrogenase was a constitutive enzyme.

Methanol oxidation by other strains of yeasts

Candida N-17, Saccharomyces $\mathrm{H}-1$ and Torulopsis $\mathrm{M}-1$ were grown on methanol, respectively. Cell-free extracts were prepared from the cells as described in Methods. The specific activity of alcohol oxidase, formaldehyde dehydrogenase and formate dehydrogenase in each extract was measured. Table VII shows the comparison of these enzymes, suggesting that methanol, formaldehyde and formate can be oxidized by Candida $\mathrm{N}-17$, Saccharomyces $\mathrm{H}-1$ and Torulopsis $\mathrm{M}-1$ as well as Candida $\mathrm{N}-16$.

\section{DISCUSSION}

Several kinds of enzyme which catalyzes the oxidation of methanol to formaldehyde in 
Table VII. Activity of Alcohol Oxidase, Formaldehyde Dehydrogenase and Formate Dehydrogenase in Extract of Methanol-Grown Yeasts

The method is shown in the text.

\begin{tabular}{lccc}
\hline & & Relative activity & \\
\cline { 2 - 4 } & $\begin{array}{c}\text { Alcohol } \\
\text { oxidase }\end{array}$ & $\begin{array}{c}\text { Formaldehyde } \\
\text { dehydrogenase }\end{array}$ & $\begin{array}{c}\text { Formate } \\
\text { dehydrogenase }\end{array}$ \\
\hline Candida N-16 & 100 & 100 & 100 \\
Candida N-17 & 95 & 108 & 97 \\
Saccharomyces H-1 & 147 & 97 & 94 \\
Torulopsis M-1 & 111 & 103 & 60 \\
\hline
\end{tabular}

bacteria have been reported. ${ }^{1 \sim 7,22 \sim 25)}$ A methanol dehydrogenase has been found in the crude extract of Pseudomonas PRL-W4 by Kaneda and Roxburgh. ${ }^{2}$ An alcohol peroxidase linked hydrogen peroxide has been suggested in Pseudomonas methanica by Harrington and Kallio." ${ }^{3)}$ A unique alcohol dehydrogenase has been reported in Pseudomonas M27 by Anthony and Zatman,, 22 25) the enzyme required both phenazine methosulphate as a primary hydrogen acceptor and ammonium ions as an activator. An enzyme similar to this alcohol dehydrogenase has been found in the extract of Pseudomonas AM $1,{ }^{51}$ Pseudomonas extroquens, ${ }^{5}{ }^{5}$ Pseudomonas methanica, ${ }^{5}$ Protaminobacter ruber ${ }^{5}$ and Methylococcus capsulatus. ${ }^{7}$ After that, Tani et al. ${ }^{11,12}$ have reported an alcohol oxidase which catalyzes the oxidation of methanol to formaldehyde in methanol-utilizing yeast, Kloeckera sp. The present authors have also isolated an alcohol oxidase from Candida $\mathrm{N}-16$ as mentioned above. Properties of this enzyme were very similar to that found in Kloeckera sp. However, no evidence has been obtained on the presence of a NAD-linked methanol dehydrogenase in Candida N-16 employed. Therefore, it seems that methanol was oxidized to formaldehyde by Candida $\mathrm{N}-16$ as the following reaction:

$$
\mathrm{CH}_{3} \mathrm{OH}+\mathrm{O}_{2} \longrightarrow \mathrm{HCHO}+\mathrm{H}_{2} \mathrm{O}_{3}
$$

Harrington and $\mathrm{Kallio}^{3)}$ indicated that metha- nol was oxidized by the extract of Pseudomonas methanica and hydrogen peroxide which was generated by a glucose-oxidase system. Catalase was found in Candida $\mathrm{N}-16$. Therefore, it would be possible that methanol was chemically oxidized by the reaction of catalase and hydrogen peroxide which had been generated by the alcohol oxidase system, although it is not clear whether alcohol oxidase and catalase are located in the same site of a cell or not. It appears that the oxidation of methanol to formaldehyde by the oxidase was not coupled to a energy-generating system, since the synthesis of ATP coupling to an oxidase reaction has not yet been reported.

Two types of formaldehyde dehydrogenase have been indicated. One is a type of the enzyme which requires both NAD and GSH and was found in beef liver ${ }^{26}$ and in Baker's yeast. $^{10,}$ A similar enzyme had also been found in the extract of Pseudomonas methanica. ${ }^{31}$ The other was a type of the enzyme which requires 2,6-dichlorophenol indophenol or phenazine methosulphate and was found in Pseudomonas AM 1. ${ }^{5}$ It was found that in Candida $\mathrm{N}-16$ formaldehyde was oxidized by a NAD-linked dehydrogenase which requires GSH. Therefore, this enzyme seems to be similar to that found in Baker's yeast.

A NAD-linked formate dehydrogenase has been found in Pseudomonas PRL-W4 $4^{2}$ and Pseudomonas AM $1^{5}$ which was grown on methanol. A similar enzyme was also found 
by the present authors in the extract of Candida $\mathrm{N}-16$.

It is considered from these results that methanol was oxidized to carbon dioxide in Candida $\mathrm{N}-16$ according to the following pathway:

$$
\mathrm{CH}_{3} \mathrm{OH} \longrightarrow \mathrm{HCHO} \longrightarrow \mathrm{HCOOH} \longrightarrow \mathrm{CO}_{2}
$$

Furthermore, it is suggested that the oxidation pathway was present not only in Candida N-16 but also in another Candida sp., Saccharomyces $\mathrm{H}-1$ and Torulopsis $\mathrm{M}-1$.

\section{REFERENCES}

1) M. Dworkin and J. W. Foster, J. Bacteriol., 72, 646 (1956).

2) T. Kaneda and J. M. Roxburgh, Can. J. Microbiol., 5, 187 (1959).

3) A. A. Harrington and R. E. Kallio, ibid., 6, 1 (1960).

4) C. Anthony and L. J. Zatman, Biochem. J., 92, 609 (1964).

5) P. A. Johnson and J. R. Quayle, ibid, 93, 281 (1964).

6) J. Heptinstall and J. R. Quayle, ibid., 117, 563 (1970).

7) R. N. Patel and D. S. Hoare, J. Bacteriol., 107, 187 (1971).

8) P. J. Large and J. R. Quayle, Biochem. J., 87, 386 (1963).

9) M. B. Kemp and J. R. Quayle, ibid., 102, 94
(1967).

10) A. J. Lawrence, M. B. Kemp and J. R. Quayle, Biochem. J., 116, 631 (1970).

11) Y. Tani, T. Miya, H. Nishikawa and K. Ogata, Agr. Biol. Chem., 36, 68 (1972).

12) Y. Tani, T. Miya and K. Ogata, ibid., 36, 76 (1972).

13) K. Tonomura, F. Kanzaki and A. Kanbayashi, Report of the Fermentation Research Institute, 41, 49 (1972).

14) D. A. MacFadyen, J. Biol. Chem., 158, 107 (1945).

15) M. A. Jermyn and R. Thomas, Biochem. J., 56, 631 (1954).

16) Z. B. Rose and E. Racker, J. Biol. Chem., 237, 3279 (1962).

17) D. C. Davison, Biochem. J., 49, 520 (1951).

18) J. I. Wenger and C. Bernofsky, Biochim. Biophys. Acta, 227, 479 (1971).

19) O. H. Lowry, N. J. Rosebrough, A. L. Farr and R. J. Randall, J. Biol. Chem., 193, 265 (1951).

20) J. H. Pazur and K. Kleppe, Biochemistry, 3, 578 (1964).

21) W. G. Heim, D. Appleman and H. T. Pyfrom, Science, 122, 693 (1955).

22) C. Aanthony and L. J. Zatman, Biochem. J., 92, 614 (1964).

23) idem, ibid., 96, 808 (1965).

24) idem, ibid., 104, 953 (1967).

25) idem, ibid., 104, 960 (1967).

26) P. Strittmatter and E. G. Ball, J. Biol. Chem., 213, 445 (1955). 